\author{
Aksel Tjora \\ Professor i sosiologi \\ Norges teknisk-naturvitenskapelige universitet \\ Foto: Eric Fagerheim
}

\title{
Medisin mellom mas, maskineri og marked
}

Når større oppmerksomhet om

helse preger stadig flere sam-

funnsområder, blir det helsesosio-

logisk relevant å forske på meka-

nismer og drivkrefter. Men hva

slags rolle skal medisinen ha

i denne utviklingen?

Det flommer over med helseråd, treningsog kostholdstips, sunne oppskrifter og all verdens piller som skal gjøre oss slanke, energiske og antioksiderte. Hvert statsbudsjett fôrer et konstant voksende helsevesen med friske penger, i år med over $10 \%$ økning ut fra regjeringens foreslåtte statsbudsjett. Vi brenner av både private og offentlige kroner i fleng til ulike behandlere og nye treningssentre, som popper opp i annethvert ledig lokale. Like fullt - selv om statistikken tydeliggjør at vi stadig lever lengre liv, er det mer uklart om vi lever bedre liv.

I forskning om pasientroller, blant annet i antologiene Den moderne pasienten (2008) og Digitale pasienter (2010), blir det tydelig at gode liv nettopp ikke er knyttet til helsevesenet. Mange pasienter log folk generelt) er «moderne» i ordets hverdagslige betydning, det vil si kompetente og nytenkende, selvstendige og informerte. Ikke minst finner vi at folk også reflekterer modernitet i mer sosiologisk forstand, med stor tro på systemer, ekspertise og profesjonelle råd. Det betyr å forvente at legen fikser problemet, og så ferdig med det!

Tvetydigheten mellom modernitetshelsevesenets paternalistiske omsorg og senmoderne refleksive individer gjør helsepolitikken kompleks og sosiologisk interessant. Og vi vil se økende avstand mellom individer som tar ansvar for sin helse på stadig nye måter, assistert av ymse dingser, apper, medieoppslag og stadig mer informasjon, og individer som ikke henger med på dette helseteknokappløpet. Markedskrefter innenfor helsedomenet vil i sin natur være kanalisert mot slike aktive og betalingsvillige individer og grupper som opprettholder sine somatiserte kroppsprosjekter, i en slags utopisk kobling mellom helseinformasjon, sensorteknologi og selvscreening. Det analytiske blikket rettes innover mot egen helse og kropp, som også vil komme til å konstituere identitet og fellesskap. Interessant nok inntar man ved disse prosjektene plass ved siden av hypokondere og grupper som de bekymrede friske og de bekymrede kanskje-friske, og ikke minst gruppen som ikke er bekymret, men tror kanskje de burde ha vært det. En form for angstdrevet marked kan dermed vokse frem på tvers av befolkningen, hvor det blir opp til hver enkelt å ta innover seg utfordringen og gå inn i en kroppsdisiplinert tilværelse med strenge dietter og treningsmani eller gi fullstendig blaffen i alt maset.

Helsesosiologien er blant annet opptatt av analyser av drivkreftene bak slike prosesser. Særlig medikaliseringshypotesen har stått sterkt, hvor medisinen får en sentral posisjon i samfunnet og hvor stadig flere avvik gjøres medisinsk relevante. I lys av utviklingstrekk karikert over blir særlig de teknologiske drivkreftene relevante. På nasjonalt nivå synes helsesektoren å være stadig mer besatt av troen på teknologi, innovasjon og næringsutvikling. Såkalte velferdsteknologier skal løse de viktigste utfordringer, og Helse- og omsorgsdepartementets ferske forskningsstrategi HelseOmsorg21 tydeliggjør helsefeltet mer som arena for markeds- og teknologiutvikling enn som folkestyrt velferdstjeneste.

I et bredere samfunnsperspektiv kan den teknologiske dreiningen av klinisk arbeid log finansieringl kritiseres for å skape en prioritetsmessig forskyvning mot områder med teknisk løsbar diagnostikk og behandling. Den kan også innebære en innsnevring av helsetjenestene til stadig mer teknisk rettet reparasjon, som både kan utfordre og gi spillerom for andre sektorer for å utvikle nye varianter av forebygging og rehabilitering. Som bredt orientert samfunnsforsker ser jeg stadig tydeligere at andre fenomener jeg studerer, som nærmiljø, byer, organisering, kafeer, festivaler og ulike kommunikasjonsmedier, har betydelig relevans for helse, om enn mer implisitt og indirekte. Gode boliger og naboskap, trygge arbeidsplasser, festlige feiringer og tilgjengelige fysiske og digitale møteplasser skaper muligheter for rike og gode liv. Det er på slike arenaer man kan redusere sosiale problemer og skape løsninger før de eskalerer til helsetrøbbel som må håndteres profesjonelt. Poenget er da at sunne liv skapes før helse blir et tema. Maset om helserelaterte tiltak blir aldri aktuelt når folkehelse kommer som en bonus av morsomme og aktive liv.

For helsepolitikken betyr en slik bredere tilnærming et tettere samarbeid med andre politikkområder. Særlig på kommunalt nivå ligger det en utfordring $\mathrm{i}$ å se sammenhengen mellom investeringer $\mathrm{i}$ ulike etater samt gjennom utvikling av samarbeidsrelasjoner med næringsliv og frivillig sektor. For den medisinske profesjon betyr det å tydeliggjøre medisinens grenser - å begrense innsatsen der den gjør liten forskjell - og ikke minst å fôre en slik holdning inn i helsepolitikken. Når folk kveles mellom risikomas og helsetrøkk, er det mye som tyder på at det er standhaftige fagfolk som best kan holde $i$ hevd en godt begrunnet skepsis til reformer og endringer som drives frem av helt andre drivkrefter enn god helse til flest mulig. Mellom mas, maskineri og marked må medisinen være pasientens allierte.

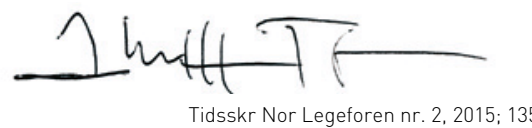

